\title{
PENGARUH KEPRIBADIAN TERHADAP KEPUTUSAN KONSUMEN MEMBELI PRODUK ROKOK CLAS MILD KOTA PALU (Studi pada Konsumen di Kota Palu)
}

\author{
MUH. AFANDI \\ SUARDI \\ MUZAKIR TOMBOLOTUTU \\ Jurusan Manajemen, Fakultas Ekonomi, Universitas Tadulako \\ Email: muhamadafandi41@gmail.com
}

\begin{abstract}
The objective of this research is to know the effect of personality factor which consists of age dimension and life cycle stage, occupation and economic circumstances, personality and self-concept as well as lifestyle and values simultaneously and partial to the purchase of Clas Mild cigarette in Palu. The researcher takes 97 samples of respondents by using purposive sampling method, and data analysis tool used is multiple linear regression. Based on the result of multiple linear regression test, can be concluded: simultaneously the personality factor which consists of age dimension and life cycle stage, occupation and economic circumstances, personality and self-concept as well as lifestyle and values simultaneously and partial to the purchase of Clas Mild cigarette in Palu with the significant value $F$ is $0,000<0.05$. The age partial and life cycle stage, occupation and economic circumstances, personality and sellf-concpt as well as lifestyle and values are influenced significantly to the purchase of Clas Mild cigarette in Palu. The value of age and life cycle stage are $0.004<0.05$, occupation and economic circumstance are $0.009<0.05$, personality and self-concept are $0.027<0,05$, life style and value are $0.02<0.05$.
\end{abstract}

Keywords: Personality factor, purchase decision.

\begin{abstract}
ABSTRAK
Penelitian ini bertujuan untuk mengetahui pengaruh faktor kepribadian terhadap keputusan pembelian produk rokok Clas Mild di Kota Palu. Permasalahan yang dikemukakan dalam penelitian ini adalah apakah faktor kepribadian, yang terdiri dari dimensi usia dan tahap siklus hidup, pekerjaan dan keadaan ekonomi, kepribadian dan konsep diri serta gaya hidup dan nilai secara simultan dan parsial berpengaruh signifikan terhadap pembelian rokok Clas Mild di Kota Palu. Dari permasalahan di atas, diajukan hipotesis faktor kepribadian, yang terdiri dari dimensi usia dan tahap siklus hidup, pekerjaan dan keadaan ekonomi, kepribadian dan konsep diri serta gaya hidup dan nilai secara simultan dan parsial berpengaruh signifikan terhadap pembelian rokok Clas Mild di Kota Palu. Sampel penelitian sebanyak 97 responden dan teknik penentuan sampel menggunakan metode purposive sampling. Membuktikan hipotesis tersebut, peneliti menggunakan Analisis Regresi Linear Berganda. Hasil penelitian ditemukan bahwa secara simultan faktor kepribadian, yang terdiri dari dimensi usia dan tahap siklus hidup, pekerjaan dan keadaan ekonomi, kepribadian dan konsep diri serta gaya hidup dan nilai berpengaruh signifikan terhadap pembelian rokok Clas Mild di Kota Palu dengan nilia sig. F sebesar $0.0000<0.05$. Secara parsial usia dan tahap siklus hidup, pekerjaan dan keadaan ekonomi, kepribadian dan konsep diri serta gaya hidup dan nilai berpengaruh signifikan terhadap pembelian rokok Clas Mild di Kota Palu dengan nilai usia dan tahap siklus hidup (X1) sebesar $0.004<0.05$, pekerjaan dan keadaan ekonomi (X2) sebesar $0.009<0.05$, kepribadian dan konsep diri (X3) sebsar $0.027<0.0$, seta gaya hidup dan nilai (X4) sebesar $0.02<0.05$.
\end{abstract}

Kata Kunci: Faktor kepribadian, keputusan pembelian.

\section{PENDAHULUAN}

Rokok telah menjadi salah satu penyebab kematian paling besar dibanyak negara di dunia, terutama di negara-negara maju. Oleh sebab itu, banyak negara yang mulai menerapkan gaya hidup sehat dengan menetapkan batasan kepada warganya untuk merokok, baik melalui kewajiban 
memasang pesan layanan masyarakat tentang bahaya merokok pada setiap iklannya, maupun melalui pembatasan tempat-tempat untuk merokok. Di Indonesia, pemerintah telah menetapkan agar setiap iklan dan kemasan rokok mencantumkan pesan layanan masyarakat tentang bahaya yang ditimbulkan akibat rokok. Pesan tersebut berbunyi: "Merokok dapat menyebabkan kanker, serangan jantung, impotensi dan gangguan kehamilan dan janin", Meskipun iklan layanan masyarakat ini telah lama diterapkan secara luas, bahkan pemerintah juga telah memperbarui pesan layanan iklannya yang berbunyi: "Merokok membunuhmu" namun hasilnya masih belum nampak secara nyata. Karna di Indonesia dalam hal pemasaran produk rokok merupakan yang paling banyak diminati oleh kehidupan masyarakat disemua golongan.

Kenaikan jumlah perokok ini mendorong bagi industri rokok untuk terus berinovasi. Begitu pula dengan rokok Clas Mild di tengah ketatnya persaingan produsen-produsen rokok, Clas Mild terus berkembang dan berinovasi. Penyebaran produk rokok Clas Mild di Indonesia tidak hanya ada di wilayah Pulau Jawa namun juga di luar Pulau Jawa yaitu di Pulau Sulawesi terkhususnya di Kota Palu. Kota Palu dalam hal pemasaran produk rokok Clas Mild ini sangat disukai masyarakat. Hal ini ditunjukkan dari banyaknya pusat-pusat pembelanjaan, toko-toko dan warung-warung yang menyediakan produk rokok ini. Karena semakin banyak produk rokok yang ada di pasaran berarti memberikan kemudahan bagi konsumen untuk memilih produk yang sesuai dengan keinginannya.

Kotler dan Keller (2012:151) a consumer's buying behavior is influenced by cultural, social, psikologis and personal factors. Artinya perilaku pembelian konsumen dipengaruhi oleh faktor budaya, sosial, psikologis dan faktor kepribadian. Demikian pula halnya perilaku konsumen dalam membuat keputusan pembelian pada produk rokok Clas Mild di Kota Palu. Produk rokok Clsss Mild merupakan barang yang spesial dan mudah di bawah kemana-mana. Rokok Clas Mild juga dapat membantu untuk mempermudah setiap kegiatan seseorang, maka proses keputusan pembelian terhadap produk ini dipengaruhi oleh unsur faktor kepribadian dari setiap konsumen.

Faktor kepribadian ini meliputi: 1) Usia dan tahap siklus hidup, yaitu keadaan yang menggambarkan riwayat manusia sejak awal tahun kehidupan sampai dengan akhir kehidupannya, 2) Pekerjaan dan keadaan ekonomi yaitu jenis mata pencarian yang menjadi sumber penghasilan seseorang dan tingkat kesejahteraan seseorang dalam kehidupannya yang dilihat pada penghasilan yang dapat dibelanjakan, tabungan dan aktiva, hutang, kemampuan untuk meminjam dan suka atas belanja atau menabung, 3) gaya hidup dan nilai yaitu pola hidup seseorang di dunia yang tercermin dalam kegiatan, minat dan perndapatan serta perilaku atau sikap menentukan keinginan dan pilihan seseorang dalam jangka panjang, 4) Kepribadian dan konsep diri yaitu pola perilaku yang konsisten dan bertahan lama yang ada pada diri seseorang dan dinilai memilki pengaruh terhadap perilaku konsumen dalam memutuskan membeli produk rokok Clas Mild di Kota Palu. Berdasarkan hal tersebut, maka tujuan penelitian ini:

1. Untuk mengetahui apakah faktor kepribadian, yang terdiri dari dimensi usia dan tahap siklus hidup, pekerjaan dan keadaan ekonomi, kepribadian dan konsep diri serta gaya hidup dan nilai secara simultan berpengaruh signifikan terhadap keputusan pembelian rokok Clas Mild di Kota Palu.

2. Untuk mengetahui apakah usia dan tahap siklus hidup secara parsial berpengaruh signifikan terhadap keputusan pembelian rokok Clas Mild di Kota Palu?

3. Untuk mengetahui apakah pekerjaan dan keadaan ekonomi secara parsial berpengaruh signifikan terhadap keputusan pembelian rokok Clas Mild di Kota Palu?

4. Untuk mengetahui apakah kepribadian dan konsep diri secara parsial berpengaruh signifikan terhadap keputusan pembelian rokok Clas Mild di Kota Palu?

5. Untuk mengetahui apakah gaya hidup dan nilai secara parsial berpengaruh signifikan terhadap keputusan pembelian rokok Clas Mild di Kota Palu?

\section{KAJIAN LITERATUR DAN PENGEMBANGAN HIPOTESIS Pengertian Pemasaran dan Manajemen Pemasaran}

Kotler dan Keller (2012:5) marketing is about identifying and meeting human and social needs. Marketing is a societal process by which individuals and groups obtain what they need and want through creating, offering, and freely exchanging products and services of value with others. Artinya 
pemasaran mengidentifikasi dan memenuhi kebutuhan manusia dan sosial. Pemasaran secara sosial adalah sebuah proses kemasyarakatan di mana individu dan kelompok memperoleh apa yang mereka butuhkan dan inginkan dengan menciptakan, menawarkan, dan secara bebas mempertukarkan produk dan jasa yang bernilai dengan orang lain.

Kotler dan Keller (2012:5) the aim of marketing is to know and understand the customer so well that the product or service fits him and sells itself. Artinya tujuan pemasaran adalah mengetahui dan memahami pelanggan dengan baik, sehingga produk atau jasa bisa sesuai dengan kebutuhannya agar terjual sendiri. Hasan (2013:4) pemasaran adalah proses mengidentifikasi, menciptakan dan mengkomunikasikan nilai, serta memelihara hubungan yang memuaskan pelanggan untuk memaksimalkan keuntungan perusahaan.

Kotler dan Keller (2012:5) marketing management as the art and science of choosing target markets and getting, keeping, and growing customers through creating, delivering, and communicating superior customer value. Artinya manajemen pemasaran adalah seni dan sains memilih pasar sasaran untuuk mendapatkan, mempertahankan, serta menumbuhkan pelanggan dengan menciptakan, menghantarkan, dan mengkomunikasikan nilai pelanggan yang unggul. Tjiptono (2011:2) manajemen pemasaran merupakan sistem total aktivitas bisnis yang dirancang untuk merencanakan, menetapkan harga, dan mendistribusikan produk, jasa dan gagasan yang mampu memuaskan keinginan pasar sasaran dalam rangka mencapai tujuan organisasional.

\section{Perilaku Konsumen}

Kotler dan Keller (2012:151) consumer behavior is the study of how individuals, groups, and organizations select, buy, use, and dispose of goods, services, ideas, or experiences to satisfy their needs and wants. Artinya perilaku konsumen adalah studi tentang bagaimana individu, kelompok dan organisasi memilih, membeli, menggunakan, dan menghabiskan barang, jasa, ide atau gagasan untuk memuaskan kebutuhanan dan keinginan mereka.

Hasan (2013:161) perilaku konsumen adalah studi proses yang terlibat ketika individu atau kelompok memilih, membeli, menggunakan, atau mengatur produk, jasa, ide atau gagasan untuk memuaskan kebutuhan dan keinginan konsumen. Nugroho (2015:2) perilaku konsumen adalah tindakan yang langsung terlibat dalam mendapatkan, mengkonsumsi, dan menghabiskan produk atau jasa, termasuk keputusan yang mendahului dan menyusuli tindakan ini

\section{Faktor-faktor yang mempengaruhi Perilaku Konsumen}

Memahami perilaku konsumen perlu dipahami siapa konsumen, sebab dalam suatu lingkungan yang berbeda akan memiliki penelitian, kebutuhan, pendapat, sikap dan selera yang berbeda-beda. Kotler dan Keller (2012:151) a consumer's buying behavior is influenced by cultural, social, psikologis and personal factors. Artinya perilaku pembelian konsumen dipengaruhi oleh faktor budaya, sosial, psikologis dan faktor kepribadian.

1. Faktor budaya terdiri dari budaya, subbudaya dan kelas sosial.

2. Faktor sosial terdiri dari kelompok referensi, keluarga, serta peran dan status.

3. Faktor pribadi terdiri dari usia dan tahap siklus hidup, pekerjaan dan keadaan ekonomi, kepribadian dan konsep diri serta gaya hidup dan nilai.

4. Faktor psikologi terdiri dari motivasi, persepsi, pembelajaran dan memori.

\section{Keputusan Pembelian Konsumen}

Keputusan pembelian konsumen merupakan bagian utama dari perilaku konsumen yang tidak dapat dipisahkan sebelum menetapkan keputusan untuk mengggunakan atau tidak menggunakan produk yang ditawarkan perusahaan. Kotler dan Keller (2012:166) that purchasing decisions are made up of five stages. Artinya bahwa keputusan pembelian terdiri dari lima tahap.

1. Pengenalan Masalah (Problem Recognition).

2. Pencarian Informasi (Information Search).

3. Evaluasi Alternatif (Evaluation of alternatives)

4. Keputusan membeli (Purchase Decision).

5. Perilaku Pasca Pembelian (Postpurchase Behavior). 


\section{Pengertian Produk}

Konsep produksi berpendapat bahwa konsumen akan menyukai produk yang berkualitas dengan harga yang relatif murah. Sangadji, dkk (2013:15) produk adalah segala sesuatu yang dapat ditawarkan kepasar untuk memenuhi kebutuhan dan keinginan konsumen.

Konsep dan pengertian produk dikemukakan oleh Kotler dan Keller (2012:325):

Product is a key element in the market offering. To achieve market leadership, firms must offer products and services of superior quality that provide unsurpassed customer value. Many people think a product is tangible, but a product is anything that can be offered to a market to satisfy a want or need, including physical goods, services, experiences, events, persons, places, properties, organizations, information, and ideas.

Artinya produk adalah elemen kunci dalam penawaran pasar. Untuk mencapai kepemimpinan pasar, perusahaan harus menawarkan produk dan jasa bermutu tinggi yang memberikan nilai pelanggan yang paling unggul (Produk adalah segala sesuatu yang dapat ditawarkan ke pasar untuk memenuhi keinginan atau kebutuhan, termasuk barang fisik, jasa, pengalaman, peristiwa, orang, tempat, properti, organisasi, informasi, dan gagasan.

\section{Kerangka Pemikiran}

Faktor kepribadian yang terdiri dari dimensi usia dan tahap siklus hidup, pekerjaan dan keadaan ekonomi, kepribadian dan konsep diri serta gaya hidu dan nilai pembeli, secara parsial dan simultan cenderung berpengaruh terhadap keputusan pembelian, dalam hal ini membeli produk Clas Mild di Kota Palu. Berdasarkan dimensi dari variabel inilah pengaruh faktor kepribadian terhadap keputusan pembelian produk rokok Clas Mild di Kota Palu dapat diteliti. Secara sistematik kerangka penilitian dapat digambarkan sebagai berikut:

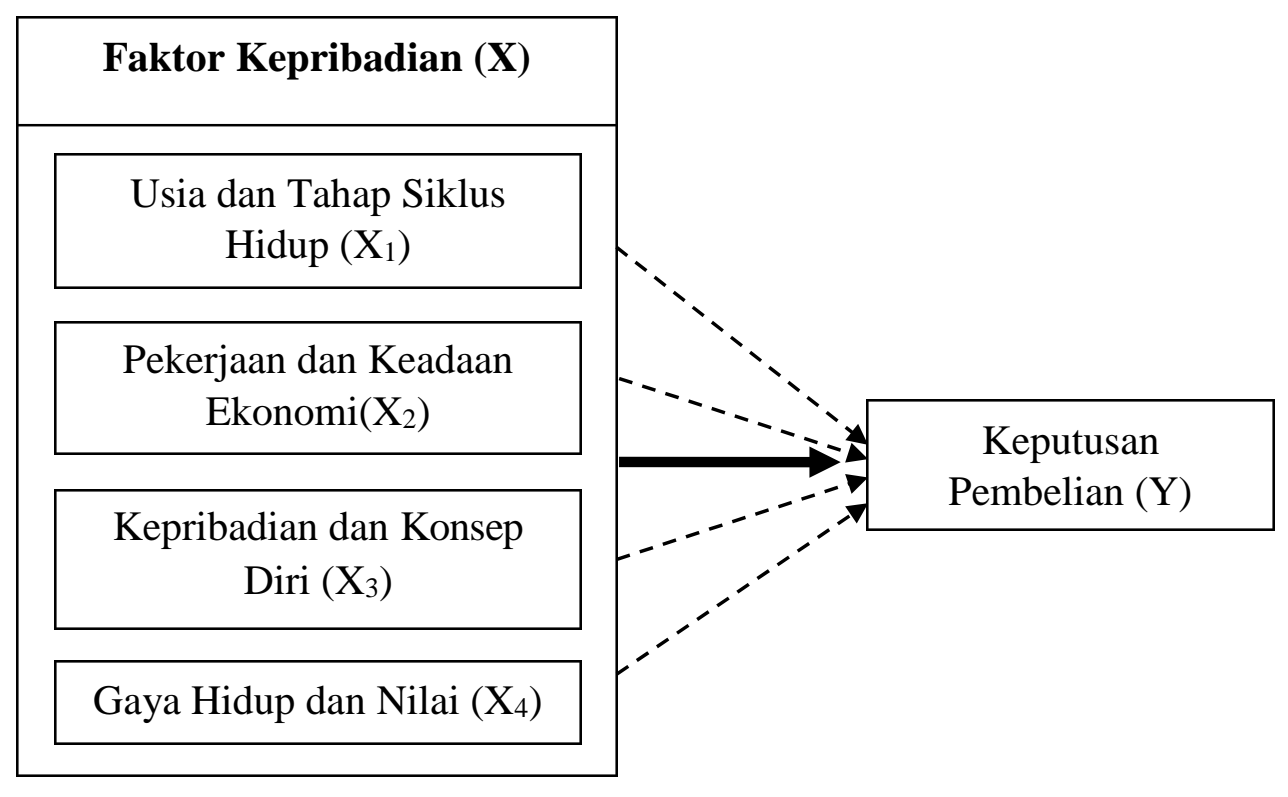

Sumber: Kotler dan Keller (2012:151)

\section{Gambar 1 \\ Kerangka Pemikiran}

\section{Hipotesis}

Adapun hipotesis yang digunakan dalam penelitian ini adalah:

1. Faktor kepribadian, yang terdiri dari dimensi usia dan tahap siklus hidup $\left(\mathrm{X}_{1}\right)$, pekerjaan dan keadaan ekonomi $\left(\mathrm{X}_{2}\right)$, kepribadian dan konsep diri $\left(\mathrm{X}_{3}\right)$, serta gaya hidup dan nilai $\left(\mathrm{X}_{4}\right)$ secara simultan berpengaruh signifikan terhadap keputusan pembelian rokok Clas Mild di Kota Palu.

2. Usia dan tahap siklus hidup $\left(\mathrm{X}_{1}\right)$ secara parsial berpengaruh signifikan terhadap keputusan pembelian rokok Clas Mild di Kota Palu. 
3. Pekerjaan dan keadaan ekonomi $\left(\mathrm{X}_{2}\right)$ secara parsial berpengaruh signifikan terhadap keputusan pembelian rokok Clas Mild di Kota Palu.

4. Kepribadian dan konsep diri $\left(\mathrm{X}_{3}\right)$ secara parsial berpengaruh signifikan terhadap keputusan pembelian rokok Clas Mild di Kota Palu.

5. Gaya hidup dan nilai $\left(\mathrm{X}_{4}\right)$ secara parsial berpengaruh signifikan terhadap keputusan pembelian rokok Clas Mild di Kota Palu.

\section{METODE PENELITIAN}

Tipe penelitian yang digunakan dalam penelitian ini adalah Deskriptif Kausal. Sugiyono (2014:53) Penelitian deskriptif adalah rumusan masalah yang berkenaan dengan pertanyaan terhadap keberadaan variabel mandiri, baik hanya satu variabel atau lebih (variabel mandiri adalah variabel yang berdiri sendiri, bukan variabel independen, karena kalau variabel independen selalu dipasangkan dengan variabel dependen). Sumber data yang digunakan dalam penelitian ini adalah:

1. Data Primer: Data primer dalam penelitian ini diperoleh dari hasil pengisian kuesioner yang diberikan oleh penulis kepada para responden mengenai identitas responden serta tanggapan dari responden setelah memutuskan untuk membeli produk rokok Clas Mild.

2. Data Sekunder: Data Sekunder dalam penelitian ini adalah sumber tertulis seperti sumber buku, jurnal dan dokumen-dokumen dari pihak yang terkait mengenai masalah pengaruh faktor kepribadian terhadap keputusan pembelian produk rokok Clas Mild di Kota Palu.

Teknik Pengumpulan Data yang digunakan adalah:

1. Observasi/Pengamatan Langsung: Supriyati (2011:46) observasi adalah suatu cara untuk mengumpulkan data penelitian dengan mempunyai sifat dasar naturalistik yang berlangsung dalam konteks natural, pelakunya berpartisipasi secara wajar dalam interaksi.

2. Dokumentasi: Husein Umar (2013:30) menyatakan bahwa dokumentasi merupakan pengumpulan data yang dilakukan dengan menelaah dokumen-dokumen yang terdapat pada perusahaan.

3. Kuesioner: Kuesioner yang dibagikan secara langsung oleh penulis kepada responden yang ditemui secara langsung di lokasi penelitian.

4. Studi Kepustakaan: Merupakan teknik pengumpulan data dengan cara membaca, mengamati dan mengolah buku, jurnal dan penelitian-penelitian terdahulu serta catatan yang menunjang penelitian ini.

Sugiyono (2014:389) populasi adalah wilayah generalisasi yang terdiri atas: Obyek atau subyek yang mempunyai kualitas dan karakteristik tertentu yang ditetapkan oleh peneliti untuk dipelajari dan kemudian ditarik kesimpulannya. Populasi dalam penelitian ini adalah masyarakat Kota Palu yang merupakan konsumen rokok Clas Mild. Sugiyono (2014:389) Sampel adalah sebagian dari populasi itu. Besarnya sampel ditentukan berdasarkan rumus Widiyanto (2012:58) sebagai berikut:

$$
n=\frac{Z^{2}}{4(\mathbf{m o e})^{2}}
$$

Keterangan:

$$
\begin{aligned}
& \mathrm{n}=\text { Banyak Sampel yang diperlukan } \\
& \mathrm{Z} \quad=\text { Tingkat Keyakinan (sebesar } 95 \% \text { atau } \mathrm{Z}=1.96 \text { ) } \\
& \text { Moe } \quad=\text { Margin of Error (moe sebesar 10\%) } \\
& \mathrm{n}=\frac{1,96^{2}}{4(0,1)^{2}} \\
& \mathrm{n}=96,4 \\
& \mathrm{n}=97 \text { (dibulatkan) }
\end{aligned}
$$


Berdasarkan penjelasan rumus di atas maka diperoleh jumlah sampel yang diambil dalam penelitian ini adalah sebanyak 97 responden. Pemilihan sampel dilakukan dengan menggunakan metode purposive sampling, yaitu teknik penentuan sampel dengan pertimbangan tertentu (Sugiyono, 2014:392). Kriteria-kriteria yang akan digunakan dalam pemilihan sampel dalam penelitian ini adalah sebagai berikut:

1. Berusia 20 tahun keatas.

2. Telah Mengkonsumsi rokok Clas Mild selama 3 tahun.

Analisis data yang digunakan adalah rengersi linier berganda. Regresi regresi linear berganda ditetapkan berdasarkan rumus Sugiyono (2014:277) berikut ini:

$$
\mathbf{Y}=\mathbf{a} \quad \mathbf{b}_{\mathbf{n}} \mathbf{X}_{\mathbf{n}}
$$

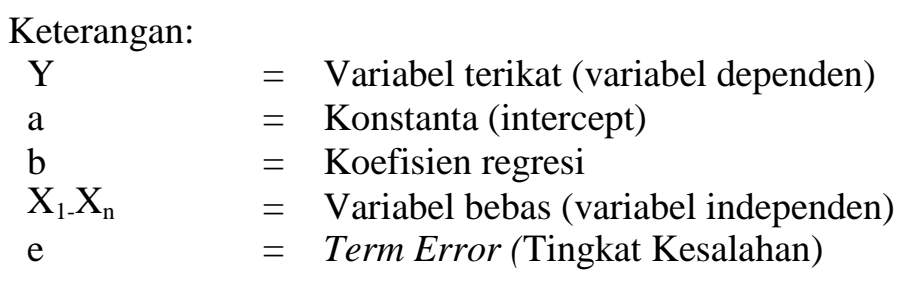

\section{HASIL DAN PEMBAHASAN}

\section{Tabel 1}

Hasil Uji Analisis Regresi Linear Berganda

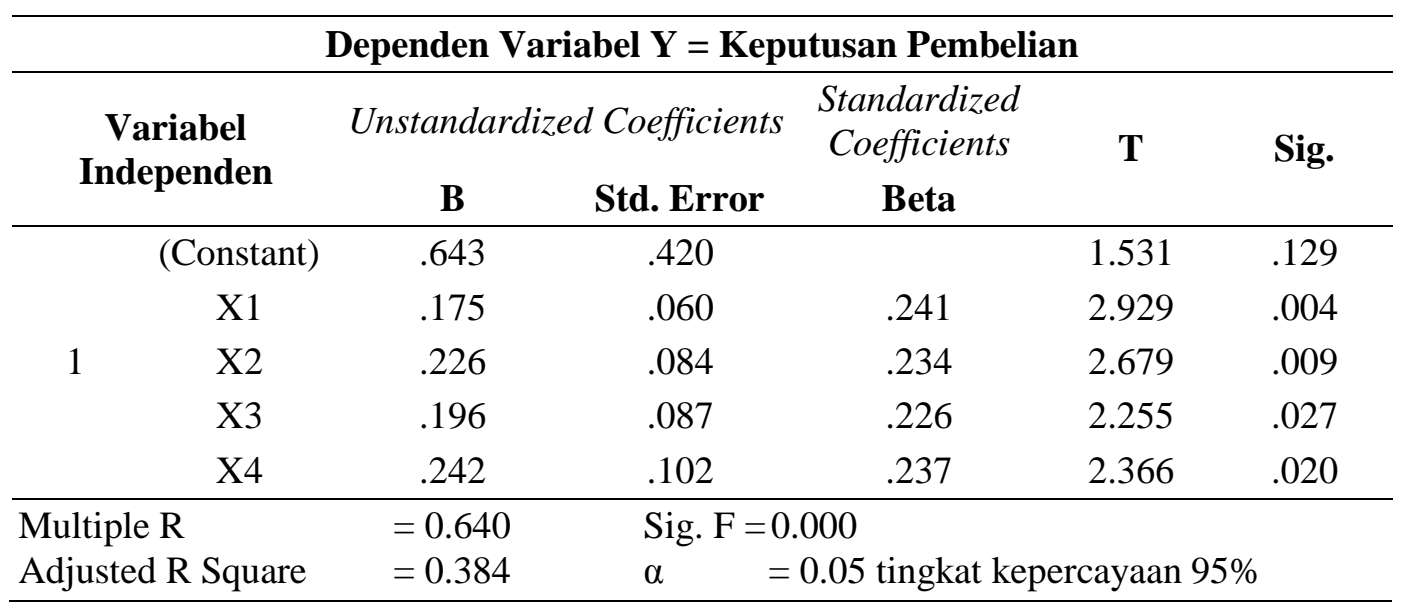

Berdasarkan Tabel 1 di atas, dapat di tulis dalam bentuk persamaan regresi linear berganda, untuk lebih jelasnya bentuk persamaan tersebut dapat dilihat sebagai berikut:

$$
Y=0.643+0.175 X_{1}+0.226 X_{2}+0.196 X_{3}+0.242 X_{4}
$$

Berdasarkan penjabaran di atas menunjukkan bahwa, variabel independen yang dianalisis yang terdiri dari dimensi $\left(\mathrm{X}_{1}, \mathrm{X}_{2}, \mathrm{X}_{3}\right.$ dan $\left.\mathrm{X}_{4}\right)$ memberikan pengaruh posotif terhadap variabel dependen $(\mathrm{Y})$, yaitu keputusan konsumen membeli produk rokok Clas Mild di Kota Palu. Untuk lebih jelasnya bentuk persamaan tersebut dapat dilihat berikut ini:

1. Nilai Konstanta sebesar 0.643 , artinya jika dimensi (usia dan tahap siklus hidup, pekerjaan dan keadaan ekonomi, kepribadian dan konsep diri, serta gaya hidup dan nilai) bernilai 0 , maka variabel dependen (keputusan pembelian produk rokok Clas Mild di Kota Palu) nilainya sebesar 0.643 .

2. Koefisien regresi dimensi usia dan tahap siklus hidup $\left(\mathrm{X}_{1}\right)$ sebesar 0.175 , artinya jika usia dan tahap siklus hidup naik satu satuan, maka keputusan pembelian produk rokok Clas Mild di Kota Palu naik sebesar 0.175 . 
3. Koefisien regresi dimensi pekerjaan dan keadaan ekonomi $\left(\mathrm{X}_{2}\right)$ 0.226, artinya jika pekerjaan dan keadaan ekonomi naik satu satuan, maka keputusan pembelian produk rokok Clas Mild di Kota Palu naik sebesar 0.226 .

4. Koefisien regresi dimensi kepribadian dan konsep diri $\left(\mathrm{X}_{3}\right)$ 0.196, artinya jika kepribadian dan konsep diri naik satu satuan, maka keputusan pembelian produk rokok Clas Mild di Kota Palu naik sebesar 0.196 .

5. Koefisien regresi dimensi gaya hidup dan nilai $\left(\mathrm{X}_{4}\right)$ 0.242, artinya jika gaya hidup dan nilai naik satu satuan, maka keputusan pembelian produk rokok Clas Mild di Kota Palu naik sebesar 0.242.

\section{Hasil Pengujian Hipotesis Secara Simultan (Uji F)}

Berdasarkan hipotesis pertama adalah untuk mengetahui apakah variabel faktor kepribadian yang terdiri dari usia dan tahap siklus hidup, pekerjaan dan keadaan ekonomi, kepribadian dan konsep diri, serta gaya hidup dan nilai secara simultan berpengaruh signifikan terhadap keputusan pembelian rokok Clas Mild di Kota Palu. Untuk lebih jelasnya hasil dapat dilihat pada Tabel 2 berikut:

Tabel 2 Hasil Uji F

\begin{tabular}{|c|c|c|c|c|}
\hline & Model & $\mathrm{F}$ & Sig. & F-Tabel \\
\hline \multirow{3}{*}{1} & Regression & 15.951 & $.000^{\mathrm{a}}$ & 2.470 \\
\hline & Residual & & & \\
\hline & Total & & & \\
\hline
\end{tabular}

Berdasarkan Tabel 2 di atas, diperoleh Sig.F yaitu 0.000, artinya nilai tersebut lebih kecil dibandingkan dengan nilai yang disyaratkan yaitu $\alpha=0.05$ dengan tingkat kepercayaan $95 \%$. Hasil fhitung diperoleh sebesar 15.951 artinya nilai tersebut > f-tabel sebesar 2.470. Dapat disimpulkan bahwa faktor kepribadian yang terdiri dari usia dan tahap siklus hidup, pekerjaan dan keadaan ekonomi, kepribadian dan konsep diri, serta gaya hidup secara simultan berpengaruh signifikan terhadap keputusan pembelian rokok Clas Mild di Kota Palu, dengan demikian hipotesis ini diterima.

\section{Hasil Pengujian Hipotesis Secara parsial (Uji t)}

Tabel 3 Hasil Uji t

\begin{tabular}{ccccc}
\hline & Model & $\boldsymbol{\Gamma}$ & Sig & T-Tabel \\
\hline \multirow{4}{*}{$\mathbf{1}$} & (Ccnstant) & 1.531 & .129 & \\
& $\mathrm{X}_{1}$ & 2.929 & .004 & 1.986 \\
& $\mathrm{X}_{2}$ & 2.679 & .079 & 1.986 \\
& $\mathrm{X}_{3}$ & 2.255 & .027 & 1.986 \\
& $\mathrm{X}_{4}$ & $2.3 \underline{66}$ & $.02 \underline{20}$ & 1.986
\end{tabular}

Berdasarkan Tabel 3 di atas, hasil uji t pengujian dimensi $\left(\mathrm{X}_{1}-\mathrm{X}_{4}\right)$ terhadap Y dijelaskan sebagai berikut:

\section{Hasil Pengujian Hipotesis $X_{1}$ terhadap $Y$}

Hipotesis kedua adalah untuk mengetahui apakah dimensi usia dan tahap siklus hidup $\left(\mathrm{X}_{1}\right)$ secara parsial berpengaruh signifikan terhadap keputusan pembelian rokok Clas Mild di Kota Palu. Berdasarkan tabel di atas menunjukkan bahwa usia dan tahap siklus hidup $\left(\mathrm{X}_{1}\right)$ memiliki nilai signifikan sebesar 0.004. Artinya nilai tersebut lebih $<$ dari taraf yang disyaratkan yaitu $\alpha=0.05$ dengan tingkat kepercayaan 95\%. Hasil t-hitung diperoleh sebesar 2.929 artinya nilai tersebut $>\mathrm{t}$ tabel sebesar 1.986, dengan demikian hipotesis ini diterima.

\section{Hasil Pengujian Hipotesis Hasil $X_{2}$ terhadap $Y$}

Hipotesis ketiga adalah untuk mengetahui apakah dimensi pekerjaan dan keadaan ekonomi $\left(\mathrm{X}_{2}\right)$ secara parsial berpengaruh signifikan terhadap keputusan pembelian rokok Clas Mild di Kota Palu. 
Berdasarkan tabel di atas menunjukkan bahwa pekerjaan dan keadaan ekonomi $\left(\mathrm{X}_{2}\right)$ memiliki nilai signifikan sebesar 0.009. Artinya nilai tersebut lebih $<$ dari taraf yang disyaratkan yaitu $\alpha=0.05$ dengan tingkat kepercayaan 95\%. Hasil t-hitung diperoleh sebesar 2679 artinya nilai tersebut $>$ ttabel sebesar 1.986, dengan demikian hipotesis ini diterima.

\section{Hasil Pengujian Hipotesis Hasil $X_{3}$ terhadap $Y$}

Hipotesis keempat adalah untuk mengetahui apakah dimensi kepribadian dan konsep diri $\left(\mathrm{X}_{3}\right)$ secara parsial berpengaruh signifikan terhadap keputusan pembelian rokok Clas Mild di Kota Palu. Berdasarkan tabel di atas menunjukkan bahwa kepribadian dan konsep diri $\left(\mathrm{X}_{3}\right)$ memiliki nilai signifikan sebesar 0.027. Artinya nilai tersebut lebih < dari taraf yang disyaratkan yaitu $\alpha=0.05$ dengan tingkat kepercayaan 95\%. Hasil t-hitung diperoleh sebesar 2.255 artinya nilai tersebut $>\mathrm{t}-$ tabel sebesar 1.986, dengan demikian hipotesis ini diterima.

\section{Hasil Pengujian Hipotesis Hasil $X_{4}$ terhadap $Y$}

Hipotesis kelima adalah untuk mengetahui apakah dimensi gaya hidup dan nilai $\left(\mathrm{X}_{4}\right)$ secara parsial berpengaruh signifikan terhadap keputusan pembelian rokok Clas Mild di Kota Palu. Berdasarkan tabel di atas menunjukkan bahwa gaya hidup dan nilai $\left(\mathrm{X}_{4}\right)$ memiliki nilai signifikan sebesar 0.020 . Artinya nilai tersebut lebih $<$ dari taraf yang disyaratkan yaitu $\alpha=0.05$ dengan tingkat kepercayaan 95\%. Hasil t-hitung diperoleh sebesar 2.366 artinya nilai tersebut $>$ t-tabel sebesar 1.986, dengan demikian hipotesis ini diterima.

\section{Pembahasan atau Hasil Analisis Secara Simultan}

Berdasarkan hasil pengujian serta analisis yang telah dilakukan pada penelitian ini membuktikan bahwa faktor kepribadian yang terdiri dari dimensi usia dan tahap siklus hidup, pekerjaan dan keadaan ekonomi, kepribadian dan konsep diri serta gaya hidup dan nilai secara simultan berpengaruh signifikan terhadap keputusan pembelian produk rokok Clas Mild di Kota Palu. Berdasarkan tabel rekapitulasi regresi linear berganda dapat dilihat pengaruh hasil uji determinasi Adjusted $R$ Square sebesar 0.384. Nilai tersebut dapat diartikan bahwa seluruh dimensi bebas yakni usia dan tahap siklus hidup, pekerjaan dan keadaan ekonomi, kepribadian dan konsep diri, serta gaya hidup mempunyai konstribusi secara bersama-sama sebesar $38.4 \%$ terhadap variabel terikat yaitu terhadap keputusan pembelian rokok Clas Mild di Kota Palu. Sedangkan sisanya $(100 \%-38.4 \%=61.6 \%)$, dipengaruhi oleh variabel lain yang tidak diteliti.

Adapun tingkat keeratan hubungan antara variabel bebas yaitu faktor pribadi terhadap variabel terikat yaitu keputusan pembelian rokok Clas Mild di Kota Palu, dapat dilihat dari nilai Multiple $\mathrm{R}$ sebesar 0.640 atau $64 \%$. hasil tersebut menunjukkan bahwa secara keseluruhan variabel bebas berhubungan cukup erat terhadap variabel terikat.

\section{Pembahasan atau Hasil Analisis Secara Parsial Usia dan Tahap Siklus Hidup $\left(\mathbf{X}_{1}\right)$}

Berdasarkan hasil pengujian serta analisis yang telah dilakukan pada penelitian ini membuktikan bahwa dimensi usia dan tahap siklus hidup berpengaruh secara parsial dan signifikan terhadap keputusan pembelian produk rokok Clas Mild di Kota Palu, di mana indikator dari dimensi usia dan tahap siklusi hidup meliputi: Kesesuaian dengan selera usia, kalangan usia dan ingin tampil lebih muda. Mean tertinggi di tempati oleh indikator kesesuaian dengan selera usia. Hal ini menunjukkan bahwa rokok Clas Mild adalah rokok sangat cocok untuk menyesuaikan dengan selera usia.

Hasil penelitian ini, dapat disimpulkan bahwa walaupun usia dan tahap siklus hidup seseorang berbeda-beda, mulai yang berusia dewasa maupun orang tua dapat mengkonsumsi rokok Clas Mild. Sehingga usia yang berbeda-beda tidak mempengaruhi keputusan konsumen membeli rokok Clas Mild. Temuan ini sejalan dengan pernyataan Kotler dan Keller (2012:155) people buy goods and services differently during their lifetime or where the needs they consume will be tailored to their age. Artinya orang membeli barang dan jasa berbeda-beda selama hidupnya atau di mana kebutuhan yang dikonsumsinnya akan disesuaikan dengan usianya. 


\section{Pekerjaan dan Keadaan Ekonomi $\left(\mathrm{X}_{2}\right)$}

Berdasarkan hasil pengujian serta analisis yang telah dilakukan pada penelitian ini membuktikan bahwa dimensi pekerjaan dan keadaan ekonomi berpengaruh secara parsial dan signifikan terhadap keputusan pembelian produk rokok Clas Mild di Kota Palu. Di mana indikator dari dimensi pekerjaan dan keadaan ekonomi meliputi: Pemikiran terbuka dan tenang saat bekerja, mempermudah aktivitas/kegiatan dan penghasilan/uang saku. Mean tertinggi di tempati oleh pemikiran tenang dan terbuka saat bekerja. Hal ini menunjukkan bahwa dengan mengkonsumsi produk rokok Clas Mild dapat membuat pemikiran terbuka dan tenang saat bekerja.

Hasil penelitian ini, dapat disimpulkan bahwa dengan mengkonsumsi rokok akan mempermudah aktivitas/kegiatan mereka saat bekerja karena dengan mengkonsumsi rokok akan membuat pemikiran mereka lebih tenang dan terbuka. Selain itu mereka yang merokok Clas Mild pada umumnya telah memiliki pekerjaan dan penghasilan yang lebih, sehingga selain membeli rokok mereka juga mampu memenuhi kebutuhan sehari-hari mereka (kebutuhan ekonomi) dan untuk anak dan istri mereka (bagi mereka yang sudah berkeluarga). Temuan ini sejalan dengan Kotler dan Keller (2012:156) occupation also influences consumption patterns. Both product and brand choice are greatly affected by economic circumstances. Artinya pekerjaan juga dipengaruhi oleh pola konsumsi. Pilihan produk dan merek sangat dipengaruhi oleh keadaan ekonomi.

\section{Kepribadian dan Konsep Diri $\left(\mathbf{X}_{3}\right)$}

Berdasarkan hasil pengujian serta analisis yang telah dilakukan pada penelitian ini membuktikan bahwa dimensi kepribadian dan konsep diri berpengaruh secara parsial dan signifikan terhadap keputusan pembelian produk rokok Clas Mild di Kota Palu. Di mana indikator dari dimensi kepribadian dan konsep diri meliputi: Percaya diri, mengekspresikan diri mereka dan kesetiaan menggunakan produk. Mean tertinggi di tempati oleh dimensi kesetiaan menggunakan produk. Hal ini menunjukkan, walaupun banyak tawaran-tawaran produk rokok lainnya konsumen yang mengkonsumsi produk rokok Clas Mild tetap setia dengan produk tersebut.

Hasil penelitian ini, dapat disimpulkan bahwa seseorang akan lebih percaya diri dan bisa mengekspresikan diri jika mengkonsumsi rokok, dan mereka akan setia dengan produk yang mereka konsumsi bilamana produk tersebut membuat mereka merasa nyaman. Temuan ini sejalan dengan pernyataan Kotler dan Keller (2012:157) brands also have personalities, and consumers are likely to choose brands and to use whose personalities match their own. Artinya merek juga memiliki kepribadian, dan konsumen cenderung memilih merek dan menggunakan yang kepribadiannya sesuai dengan keinginan mereka sendiri.

\section{Gaya Hidup dan Nilai $\left(\mathbf{X}_{4}\right)$}

Berdasarkan hasil pengujian serta analisis yang telah dilakukan pada penelitian ini membuktikan bahwa dimensi gaya hidup dan nilai berpengaruh secara parsial dan signifikan terhadap keputusan pembelian produk rokok Clas Mild di Kota Palu. Di mana indikator dari dimensi gaya hidup dan nilai meliputi: Gaya hidup, harga dan nilai produk, dan nilai yang baik. Dengan mean tertinggi di tempati oleh indikator harga dan nilai produk. Hal ini menunjukkan bahwa harga produk rokok Clas Mild sesuai dengan nilai produk.

Hasil penelitian ini, dapat disimpulkan bahwa seseorang ingin memperlihatkan dan membedakan cerminan gaya hidupnya kepada orang lain dengan membeli produk yang baik dan sesuai dengan nilai produk tersebut. Hal ini sejalan dengan pernyataan Kotler dan Keller (2012:157\&159) people from the same subculture, social class, and occupation may lead quite different lifestyles. Consumer decisions are also influenced by core values. Artinya orang-orang dari subbudaya, kelas sosial, dan pekerjaan yang sama juga mempunyai gaya hidup yang cukup berbeda. Keputusan konsumen juga dipengaruhi oleh nilai inti.

\section{KESIMPULAN DAN SARAN}

\section{Kesimpulan}

Berdasarkan hasil penelitian yang telah dijabarkan, maka diperoleh kesimpulan mengenai pengaruh faktor kepribadian terhadap keputusan pembelian produk rokok Clas Mild di Kota Palu. 
1. Faktor kepribadian, yang terdiri dari dimensi usia dan tahap siklus hidup, pekerjaan dan keadaan ekonomi, kepribadian dan konsep diri, serta gaya hidup dan nilai secara simultan berpengaruh signifikan terhadap keputusan pembelian rokok Clas Mild di Kota Palu.

2. Usia dan tahap siklus hidup secara parsial berpengaruh signifikan terhadap keputusan pembelian rokok Clas Mild di Kota Palu.

3. Pekerjaan dan keadaan ekonomi secara parsial berpengaruh signifikan terhadap keputusan pembelian rokok Clas Mild di Kota Palu.

4. Kepribadian dan konsep diri secara parsial berpengaruh signifikan terhadap keputusan pembelian rokok Clas Mild di Kota Palu.

5. Gaya hidup dan nilai secara parsial berpengaruh signifikan terhadap keputusan pembelian rokok Clas Mild di Kota Palu.

\section{Saran}

1. Bagi peneliti selanjutnya diharapkan untuk menambah variabel dalam penelitian ini, seperti faktor budaya, faktor sosial dan faktor psikologis, karena hal tersebut juga merupakan sesuatu yang dasar dari diri manusia.

2. Bagi peneliti selanjutnya diharapkan untuk menambah sampel penelitian dari segi prespektif penjualan.

\section{REFERENSI}

Ali, Hasan (2013). Marketing dan Kasus-Kasus Pilihan. Yogyakarta: CAPS

Kotler, Philip, dan Kevin Lane Keller. (2012). Marketing Manajemen. (14th ed). New Jearsey: Pearson Education, Inc.

Sangadji, Etta Mamang dan Sopiah. (2013). Perilaku Konsumen: Pendekatan Praktis Disertai

Himpunan Jurnal Penelitian. Edisi pertama. Yogyakarta: Andi.

Setiadi, Nugroho J. (2015). Perilaku Konsumen, Cetakan keenam Edisi Revisi. Jakarta: Prenamedia Group.

Sugiyono. (2014). Metode Penelitian Bisnis (Pendekatan. Kuantitatif, Kualitatif, dan R\&D), Cetakan Ke-18. Bandung: Alfabeta.

Supriyati. (2011). Belajar Akuntansi Dasar. Bandung: Labkat Press Unikom.

Tjiptono, Fandi. (2011). Pemasaran Jasa. Malang: Bayumedia.

Umar, Husein. (2013). Metode Penelitian untuk Skripsi dan Tesis. Jakarta: Rajawali

Widiyanto, (2012). Metodelogi Penelitian. Semarang: BP Undip. 